\title{
FOREIGN CORPORATION LAWS: SOURCE AND SUPPORT FOR REFORM
}

\author{
WiLliam LaURENS WaLKeR*
}

The original reason for foreign corporation laws is lost; their conceptual foundation is largely discredited, and, at most, the present utility of this expanding and complex scheme is minimal. In the face of these conditions the author turned to a search for alternatives and found in the "mutual exemption" statutes of Quebec and Ontario significant steps toward foreign corporation law reform. In the following article the author investigates, with the aid of information obtained through personal interviews and field study, the success which the two Canadian provinces have achieved with their unique arrangement.

The most significant difference between American and Canadian legislation controlling the admission of enterprises incorporated by other states or provinces is a Canadian arrangement for reciprocal exemption from qualification. In both the United States and Canada federal partners painstakingly control the entry of businesses incorporated by each other, but Quebec and Ontario; commercially the most important provinces of Canada, ${ }^{\prime}$ have, since 1930, exempted corporations chartered by the other from their troublesome foreign corporation laws.

The proposal for mutual exemption was made by Quebec in 1904 in that province's first foreign or, as the legislation is often referred to in Canada, "extra-provincial corporation law." Legislative Assembly Bill No. $3^{3}$ of that year, "An Act for the Licensing of

*Associate Proféssor of Law, University of North Carolina School of Law. A.B. 1959, Davidson College: LL.B. 1963, Duke University.

The research for this article was made possible by a grant from the University of North Carolina at Chapel Hill. The author also expresses his appreciation to the many public officials, attorneys, and scholars of Quebec and Ontario who shared their experiences with him.

'In 1965 the total manufacturing activity of Quebec and Ontario was about three times that of all other Canadian provinces combined, and in 1967 the total volume of retail trade in the two provinces was more than twice that of all other provinces. Dominion BUREAU OF Statistics. Canada Year Book 705, 895 (1968).

${ }^{2}$ An Act respecting Extra-Provincial Commercial Corporations and Joint Stock Companies, 4 Edw. 7, c. 34 (1904) (Que.) (codified at QuE. REv. STAT. c. 282 (1964)). The terms "foreign corporation law" and "extra-provincial corporation law" will be used here interchangeably.

'The bill as introduced is available in Bills, 10th Parliament, 4th Sess. (1904) (Que.) (unpublished document in the Quebec Legislative Library). 


\section{Extra-Provincial Commercia [1] Corporations and Joint Stock} Companies," was amended before enactment to exempt "[c]orporations and companies incorporated under or in virtue of an act of a Legislature of another Province of Canada where corporations and companies incorporated under and in virtue of the laws of the Province of Quebec are authorized to do business without being obliged to take out a license [t]herefor." The Ontario Legislature accepted this offer of reciprocity in 1929 by amending that province's foreign corporation law to provide that

[w] here it appears that legislation is in force in any other Province of Canada exempting corporations incorporated in Ontario from the provisions of any Act corresponding with the provisions of this Act, the Lieutenant-Governor in Council may exempt any corporation incorporated under the law of such other province from the provisions of this Act or any of them. ${ }^{5}$

Attorney-General William H. Price, who introduced the amendment, told the press: "[W]e are saying to the other provinces "Any time you incorporate a company we are willing to let that company operate in Ontario as long as you extend the same privilege in your Provinces to companies that incorporate with us." 6 The mutual arrangement became effective on February 15, 1930, when the Lieutenant-Governor in Council" exempted "any corporation incorporated under the law of the Province of Quebec."

An Act Respecting Extra-Provincial Commerical Corporations and Joint Stock Companies, 4 Edw. 7, c. 34, $\S 1$ (d) (1904) (Que.) (codified at Que. Rev. Stat. c. 282, $\S 2(4)$ (1964)).

5The Extra Provincial Corporations Act, 19 Geo. S, c. 52, $\S 2$ (1929) (Ont.) (now codified at ONT. Rev. STAT. c. 71, § 345(1) (1960)).

The Globe (Toronto), Mar. 6, 1929, at 15, col. 3. The Globe described the bill as follows: Legislation which Attorney-General Price introduced to the Legislature yesterday, under the title of "An Amendment to the Extra Provincial Corporations Act" is a small package with possibly far-reaching effects, inasmuch as it would provide an Ontario-incorporated joint stock company with the same field of operation as it might enjoy under a Dominion charter.

The bill is a new step in the Ferguson Government's policy of reciprocal legislation. At the present time this Province has reciprocal legislation with the other Provinces in several fields, including succession duties. $I d$.

'The Lieutenant-Governor is the chief executive officer of the province and is appointed by the Governor-General of Canada to represent the Crown. His present influence is very limited. See J. Saywell, The Office of Lieutenant-Governor (1957). The Ontario Executive Council is composed of persons appointed by the Lieutenant-Governor to serve as ministers of the Crown. ONt. Rev. Stat. c. 127 (1960).

Order-In-Council, Feb. 15, 1930 (Ontario) (unpublished document in the office of the Clerk of the Ontario Executive Council). The substance of the order is now incorporated in ONT. REv. REG., reg. 61, $\S 45$ (1960). 
Quebec and Ontario continue to condition the admission of businesses incorporated by other provinces, but, as a result of the events described above, each now exempts the other's corporations from qualification, a situation with no analogy among the states. This arrangement offers a unique opportunity to test assertions made clsewhere that American foreign corporation laws now serve no real needs and could be radically modified or eliminated without adverse consequence. This article examines the legal setting of the Quebec-Ontario innovation to discover the extent to which Canadian experience with these exemptions can be applied to the states, and, by reporting interviews with public officials and attorneys and other field work conducted in Canada, describes that experience and its lessons.

\section{The BRITISH NoRth America ACT}

The twenty million people of Canada are joined in a federal union and governed by a constitutional monarchy. The preamble to the British North America Act, $1867,{ }^{10}$ the written constitution of Canada, states that the original partners "[d]esire to be federally united into One Dominion under the Crown of the United Kingdom of Great Britain and Ireland, with a constitution similar in Principle to that of the United Kingdom." The federal structure is found in section 91, which establishes the "Powers of the Parliament," and Section 92, which describes the "Exclusive Powers of Provincial Legislatures";" and it is this heartland which largely determines the

\footnotetext{
Authority to ignore the reciprocity requirement was granted by An Act to Amend The Corporations Act, 4 Eliz. 2, c. 9, $\$ 19$ (1955) (Ont.) (now codified at ONT. Rev. Stat. c. $71, \S 345(2)(1960)$ ), but no exemptions have been made under the Act.

'See Walker, Foreign Corporation Laws: A Current Account, 47 N.C.L. Rev. 733 (1969); Walker, Foreign Corporation Laws: The Loss of Reason, 47 N.C.L. REv. 1 (1968).

. British North America Act, 30 \& 31 Vict., c. 3 (1867). The Act created four provinces: Quebec, Ontario, Nova Scotia, and New Brunswick. Six new provinces (Manitoba, British Columbia, Prince Edward Island, Alberta, Saskatchewan, and Newfoundland) have since been added. The newest partner is Newfoundland which joined in 1949. M. OLLIVIER, BRItISH North America Acts and Selected Statutes 64 n.6 (1962). The history of confederation is described at 1 The Royal Commission On Dominion-Provincial Relations, Report 19-29 (1940).

"Section 91 first grants to the Queen "by and with the Advice and Consent of the Senate and House of Commons" residuary law making power, and then adds a number of specific subjects which are enumerated "for greater Certainty, but not so as to restrict the Generality of the foregoing Terms of this Section." Section 92 gives provincial legislatures power to make laws in relation to sixteen specified "Classes of Subjects," the most general of which appears to be the last, "all Matters of a merely local or private Nature in the Province."
} 
position of corporations in the Canadian system. Section 91(2) of the Act, for example, confirms that the legislative authority of the Parliament includes "The Regulation of Trade and Commerce," and section 92(11) grants the provincial legislatures power to make laws in relation to "The Incorporation of Companies with Provincial Objects." The application of this and other fundamental language of the Canadian Constitution to corporations is a tangled affair, but at least the frame of this investigation can be summarized in several statements:

1. The Parliament of Canada has a general power of ineorporation. The existence of the federal authority was confirmed in Citizens Insurance Co. of Canada v. Parsons ${ }^{12}$ where the Privy Councill' held that Parliament can incorporate "by its general power over all matters not coming within the classes of subjects assigned exclusively to the legislatures of the provinces."14 The major advantage of federal incorporation is often said to be the constitutional right to operate in all of Canada, ${ }^{15}$ but despite this

The true nature of this federal mechanism is an old source of controversy in Canada. Many contend that the confederators intended a strong central government with broad powers but that the courts applied the Act in a way that nearly produced the opposite arrangement. Others, however, stress the limits of interpretation of the intentions of the founders and argue that the very existence of the French minority in Canada demanded and now demands a high degrce of provincial autonomy. Both positions are summarized in 1 THE RoYAl Commission on Dominion Provincial Relations, Report 29-36 (1940). The developments to 1966 are summarized at B. Laskin, Canadian Constitutional law 20-22 (3d ed. 1966). See also The Royal Commission on Bilingualism and Biculturalism, Report (1967).

${ }^{27}$ App. Cas. 96 (P.C. 1881) (Can.).

${ }^{13}$ From 1844 until the practice was ended in 1949 by An Act to Amend the Supreme Court Act, 13 Geo. 6, '(2d Sess.), c. 37 (1949) (Can.) appeal in a wide variety of cases lay from the highest available court in Canada to the Judicial Committee of the Privy Council, a statutory board established early in the nineteenth century primarily to, recommend disposition of appeals to the British Crown originating in the colonies. C. Pierson, CANAda and the Privy Council 1-25 (1960); MacDonald, The Privy Council and the Canadian Constitution. 29 Can. Bar Rev. 1021 (1951).

14 7 App. Cas. at 116. The Canadian Parliament acted in the field even before the existence of the power was confirmed. The first general Dominion act was The Canada Joint Stock Companies Letters Patent Act, 32 \& 33 Vict., c. 13 (1869) (Can.). The basis of the present Act is The Companies Act, 24 \& 25 Geo. 5, c. 33 (1934) (Can.), which, with amendments, is now codified at CAN. REV. STAT. c. 53 (1952). The early history of incorporation in Canada is described at F. Wegenast, Canadian Companies $20-22$ (1931). The present act is fully treated in M. Fraser \& J. Stewart, Company Law of Canada (5th ed. J. Stewart \& M. Palmer 1962).

${ }^{15}$ The right of Dominion companies to act in the provinces without substantial impediment is described in John Deere Plow Co. v. Wharton, [1915] A.C. 330 (P.C. 1914) (B. C.) and Great West Saddlery Co. v. The King, [1921] 2 A.C. 91 (P.C.) (Can.). 
suggested superiority the number of federally chartered companies remains relatively small, ${ }^{16}$ and perhaps only half of the Canadian corporations acting in more than one province are Dominion companies. ${ }^{17}$ This condition probably persists because corporations often do not expect to operate nationally when organized, and it is difficult to later change status, because provinces have been willing to admit other provinces' corporations even though not required to do so, and because attorneys often prefer the more familiar local laws. In any event, if the situation were substantially the reverse and federal corporations had become the exclusive vehicles for interprovincial corporate enterprise, this investigation would be of little immediate value because Dominion companies have no general counterparts in the United States and provincial experience with them has no application to the states.

2. Provincial corporations can act outside incorporating provinces. The British North America Act makes it clear that the provincial legislatures can incorporate,,$^{18}$ but there was for sometime doubt, analogous to that resolved in Bank of Augusta v. Earle, ${ }^{19}$ as to whether provincial companies could act beyond the boundaries of their incorporating jurisdictions. The question was settled in Bonanza Creek Gold Mining Co. v. The King ${ }^{20}$ where the Privy Council, much like the Supreme Court in Bank of Augusta, said that territorial limitations on "actual powers and rights are one thing and capacity to accept extra-provincial powers and rights is quite another," ${ }^{21}$ and held that the plaintiff Ontario corporation could accept power to do business in the Yukon Territory. ${ }^{22}$ Furthermore, in stating that "rights outside the province would have

\footnotetext{
"There are now approximately 17,000 Dominion corporations, but, for example, approximately 90,000 Ontario corporations.

${ }^{12}$ The Canada Department of Consumer and Corporate Affairs determined in August, 1968, that 71 of the 100 largest corporations in Canada by sales were Dominion companies and 29 were provincial companies. The experience of the Department suggests that as the sizes of corporate enterprises decrease the likelihood of federal charters also decreases. If nearly onethird of these largest companies are provincial corporations, it is reasonable to estimate that one-half of all corporations acting in more than one province are provincial corporations.

13The British North America Act, 30 \& 31 Vict., c. 3, § 92(11) (1867).

138 U.S. (13 Pet.) 519 (1839).

[1916] 1 A.C. 566 (P.C.) (Can.).

21 Id. at 583.

${ }^{2}$ The conflicting views which existed before the Bonanza Creek decision are described at Ziegel, Constitutional Aspects of Canadian Companies in Canadian Company Law 149, 188 (J. Ziegel ed. 1967).
} 
to be derived from authorities outside the province, ${ }^{, 23}$ the Council in Bonanza Creek established the conceptual basis for laws controlling the admission of corporations chartered by other provinces.

3. The provincial legislatures control without limitation the admission of enterprises incorporated by other provinces. The grant of power to Parliament to make laws relating to the "Regulation of Trade and Commerce" ${ }^{24}$ is the Canadian commerce clause. However, this grant has been emasculated by a line of cases beginning with Citizens Insurance Co. of Canada v. Parsons, ${ }^{25}$ which broadly described provincial authority to control "Property and Civil Rights in the Province,"26 and substantially completed with John Deere. Plow Co. v. Wharton, ${ }^{27}$ a case which apparently held that positive federal action under the commerce clause must give way to action within that provincial authority. This extreme suggestion eliminates any prospect of finding implications in the commerce clause sufficient to limit the local treatment of corporations incorporated by other provinces, and this situation has been described as "most ominous-and most damaging to the national economy."28 A similar and perhaps also "ominous" situation exists now in the United States where the American commerce clause, once an effective limit on state control of admissions of corporations chartered by other states, has had little impact for a number of years. ${ }^{29}$

The British North America Act has no requirement similar to that of Article IV, section 2, of the United States Constitution-"The Citizens of each State shall be entitled to all Privileges and Immunities of Citizens in the several States"-and no

\footnotetext{
${ }^{25}[1916] 1$ A.C. at 578-79.

21The British North America Act, 30 \& 31 Vict., c. 3, § 91 (2) (1867).

${ }^{25} 7$ App. Cas. 96 (P.C. 1881) (Can.).

${ }^{26}$ The British North America Act, 30 \& 31 Vict., c. 3, § 92(13) (1867).

${ }^{27}$ [1915] A.C. 330 (P.C.' 1914) (B. C.). The surprising language of the Board was:

[Their Lordships] do not desire to be understood as suggesting that because the status of a Dominion company eriables it to trade in a province and thereby confers on it civil rights to some extent, the power to regulate trade and commerce can be exercised in such a way as to trench, in the case of such companies, on the exclusive jurisdiction of the provincial Legislatures over civil rights in general. Id. at 340-4I.

${ }^{2}$ Ziegel, supra note 22, at 194. For a comparative description of this development see A. Smith, The Commerce Power in Canada and the United States (1963).

"Walker, Foreign Corporation Laws: A Current Account. 47 N.C.L. Rev. 733, 747-53 (1969).
} 
serious argument can be made in Canada that provincially chartered corporations are entitled in other provinces to the privileges of locally chartered corporations. But here again the difference is largely superficial because the interstate privileges and immunities clause is said not to apply to corporations because they are not "citizens" within that provision's terms. ${ }^{30}$ In addition, there is- no due process clause in the Canadian Constitution ${ }^{31}$ to require reasonable regulation of corporations from other provinces and, as a particular consequence, provinces are free to decide how corporations from other provinces will be summoned to appear in local courts and the local effect to be given judgments obtained against them. This particular condition is similar to the situation in the United States because the once stringent requirements of due process for service have been considerably relaxed. ${ }^{32}$

\section{Provincial Foreign Corporation Laws}

Nine of the ten Canadian provinces have extra-provincial corporation laws similar to their American counterparts. ${ }^{33}$ The tenth, small New Brunswick, has no traditional statute, requiring only that corporations from other provinces file annual information returns. ${ }^{34}$

\footnotetext{
"Bank of Augusta v. Earle, 38 U.S. (13 Pet.) 519 (1839); Bank of United States v. Deveaux, 9 U.S. (5 Cranch) 61 (1809). See G. Henderson, The Posmon of Foreign Corporations in American Constitutional Law 50-76 (1918).

31 "There are no explicit guarantees of civil liberties in the B.N.A. Act . . . B. LAskin, supra note 11, at 970 . In 1960 Parliament enacted the Canadian Bill of Rights, 8 \& 9 Eliz. 2, c. 44 (1960) (Can.), but it operates only at the federal level and is without effect on provincial legislatures.

${ }^{23}$ The change came in a line of cases from McDonald v. Mabee, 243 U.S. 90 (1917) to International Shoe Co. v. Washington, 326 U.S. 310 (1945), and is briefly described in Walker, Foreign Corporation Laws: The Loss of Reason. 47 N.C.L. REv. 1, $24-28$ (1968).

"The first provincial foreign corporation law was enacted by Manitoba in 1883, but most of the present acts are related to the Ontario Act of 1900 . These statutes are discussed, and the origin and history of all the provincial laws are examined at F. WEGENAST, supra note 14, at 830-35. Some of the similarity between the American and Canadian laws may be explained by the fact that, according to Wegenast, the original Ontario Act "was drafted by the late Mr. Z.A. Lash on precedents from the United States." Id. at 830 n.3. The nine current statutes are found at Alta. Rev. Stat. c. 53, §§ 146-64 (1955); B.C. Rev. Stat. c. 67, $\S$ 186-211 (1960); The Companies Act, 13 Eliz. 2 (2d Sess.), c. 3, §§ 367-91 (1964) (Man.); The Companies (Amendment) Act. 1956, 5 Eliz. 2, No. 40, \& 7 (Newf.); N.S. Rev. Stat. c. 59, §§ 28-44 (1967); ONt. Rev. Stat. c. 71, §§ 343-59 (1960); An Act to Provide for the Licensing or Registration of Certain Corporations and Persons. 11 Eliz. 2, c. 22 (1962) (Prince Edward Island); Que. Rev. Stat. c. 282 (1964); Sask. Rev. Stat. c. 131, §§ 193213 (1965).
} 


\section{General Profile}

The scopes of the nine statutes are described in terms of corporation-province contacts. All use the phrase "carry on business" rather than the typical American term of art, "doing business." All nine require applications for admission. and all require that applications state the names of corporations, jurisdictions of incorporation, addresses of principal offices, and addresses of local offices and agents. In addition, a majority of the provinces ask for statements of proposed local activities, names and addresses of officers and directors, and information about capital structures. Eight of the nine provinces require that corporations name local agents to accept service of original process, but contrary to the American pattern, none of these designation requirements is accompanied by supplementary provisions allowing service on public officials where designated agents cannot be found or where no agents have been named. Seven provinces require corporations to file copies of their incorporating documents with local officials, and a majority of the seven require that copies of subsequent changes also be filed. Only two provincial statutes specifically provide that corporations will not be admitted if their names are the same as local corporations, ${ }^{36}$ a limitation typically found in American laws. Formal grants of local powers are rare, and there are no counterparts to the statutory subjection to local law commonly found in state corporation statutes.

The housekeeping requirements of the Canadian statutes are generally the same as those of the American laws. A majority of the nine requires annual reports, but only one province, British Columbia, requires current financial information. ${ }^{37} \mathrm{~A}$ majority also

\footnotetext{
HN.B. Rev. Stat. c. 33, § 125 (1952). This legislation is innovative, but is not considered here in detail because there is no opportunity to observe old and new in the same setting, as there is in Quebec and Ontario, and because New Brunswick is not as commercially significant as the two larger provinces.

${ }^{35}$ The change in language has not made the problem of determining whether compliance is required any easier. The early cases are collected at F. WEGENAST, supra note 14, at 861-68. Later cases are at M. Fraser \& J. STEWART, supra note 14, at 79-82.

${ }^{3}$ Que. Rev. Stat. c. 282, § 4(5) (1964); ONt. Rev. Stat. c. 71, § 350(2) (1960). A similar requirement is probably administratively applied by the others.

7 B.C. Rev. STAT. c. 67, $\$ 201(2)$ (1960). But the requirement is sharply limited: "[T]his subsection does not apply to a company that is not required by or under any Statute, Act or Ordinance of the Province, State, or country where it is incorporated to make or file in a public office any report or statement of its liabilities or assets, and the report shall contain a declaration to that effect." Id.
} 
establishes procedures for withdrawals and revocations upon stated grounds. Like the states, penàlties for noncompliance, including fines, are provided for in all the extra-provincial corporation statutes. Seven statutes prevent noncomplying corporations from bringing suits in local courts, though most of these specifically provide that later qualification will be given retroactive effect, thus permitting corporations to bring suits for claims which arose prior to compliance. ${ }^{38}$

\section{Quebec and Ontario}

Both Quebec and Ontario require applications for admission, designations of local agents, filings of charter copies, and otherwise follow the statutory pattern typical in Canada and the United States. The mutual exemption arrangement, however, is unique. The statutes of both Quebec and Ontario narrow; to a degrce, the effect of the waivers by requiring all corporations from other provinces to file annual information returns. ${ }^{39}$ These statements must include

\footnotetext{
"Model corporation legislation has not had the impact in Canada that it has had in the United States where the ABA-ALI Model Business Corporation Act is now the pattern for new statutes. The explanation for the difference is probably the existence in Canada of two methods of general incorporation. The Dominion, Ontario, Quebec, Manitoba, New Brunswick, and Prince Edward Island charter companies hy letters patent. Alberta, British Columbia, Newfoundland, Nova Scotia, and Saskatchewan incorporate by registration of memoranda of association according to a procedure similar to the current British practice. Wegenast states that "the difference between passive acquiescence and positive authorization is perhaps the most important of the differences in result between the two methods of incorporation." F. WEGENAST, supra note 14, at 65 . The implications of that difference are discussed at id. 63-70. This situation has resulted in the anomaly of two "uniform" acts, now puhlished at Special Committee on Uniform Companies act of the Conference of Commissioners on Uniformity of Legislation in Canada, Revised Draft Uniform ACt (Memorandum and ARTicles) (1960) and Special Committee on Uniform Companies ACt of the Conference on Uniformity of Legislation in Canada, Revised Draft Uniform ACt (LetTERS PATENT) (1960). Neither of the acts has been influential, and comment has been sparse, but see Cudney, The Uniform Corporations Act, in Papers Presented at the Annual Meeting 141 (Can. Bar Ass'n 1960); Symposium on the Revised Draft Uniform Companies Act (Memorandum and Articles) 1960. 3 ALTA. L. Rev. 89 (1963). The Memorandum and Articles draft treats extra-provincial corporations at Part III, and establishes a system of regulation similar to the present Canadian pattern. The Letters Patent draft does not deal with extra-provincial corporations at all. This omission was probably not a radical reform but reflects an intention to leave the matter to a separate statute as, for example, is now done in Quebec.

${ }^{30}$ Que. Rev. Stat. c. 273 (1964); Ont. Rev. Stat. c. 72 (1960). The Quebec Companies Information Act requires that a return be made "by every company and syndicate, - (a) Upon the establishment in the Province of a head office or other office, and (b) Upon commencing any business in the Province...." Que. Rev. Stat. c. 273, § 2(1) (1964). The Ontario
} 
corporate names, details of incorporations, statements of local activities, names and addresses of officers and directors, addresses of specified offices, and information about capital structures. The Information Acts do not replace agent designation and charter filing requirements, the only major elements that appear in substantially all state laws. ${ }^{40}$

\section{The QuebeC EXPERIENCE}

Foreign corporation laws, though relatively brief in themselves, relate intimately to a number of sensitive areas of civil law. For example, problems in bringing out-of-state corporations into local courts caused by the decision of Pennoyer $v$. Neff ${ }^{\prime}$ were the primary motivation for the adoption of these laws by the states. The now out moded Pennoyer decision required physical delivery of process within forum states as an element of due process requisite for unlimited general jurisdiction. Quebec directly defines the situations in which a personal action can be brought in Quebec courts.12 They include: When the defendant is domiciled in Quebec; when he resides in Quebec; when he owns property in Quebec; when he is served in Quebec; when the cause of action arose in Quebec; and when the contract in suit was made in Quebec. ${ }^{43}$ The existence of any one of these conditions establishes jurisdiction. Thus, with the one exception of jurisdiction established by service on the defendant, service of process conceptually follows jurisdiction, and the Quebec Code provides for service by delivery in another province of Canada "upon proof that a party is domiciled or ordinarily resident in another province of Canada." Although the fundamental principle

Corporations Information Act requires filing by "every corporation incorporated under the laws of Ontario and every other corporation having its head or other office or carrying on business or a part thereof in Ontario ...." ONT. Rev. STAT. c. 72, § 3(I) (I960). In Quebec the requirements of the Information Act are somewhat duplicated by QUE. REv. STAT. c. 272 (1964) which requires that "[e]very incorporated company carrying on any labour, trade or business" in the province deliver to the prothonotary of the superior court of each district in which it carries on business a statement of "the name of the company, where and how it was incorporated, the date of its incorporation and where its principal place of business within the Province is situated." Id. $\S \S I(1),(2)$.

${ }^{40}$ See Walker, supra note 29, at 739.

\$195 U.S. 714 (I877).

${ }^{42}$ Que. Code Civ. P. art. 68.

"3.

"Id. art. 137.

[T]he Code of Civil Procedure does not approach the subject of jurisdiction through 
is different, in practice the results are probably comparable to those obtained in American states with relatively modest long arm statutes.

Ontario and the other provinces are free to decide what effect they will give Quebec judgments against their local provincial corporations. Because there is no full faith and credit clause in the British North America Act, Canadian provinces can give the same regard to judgments obtained against local corporations in other provinces as they would judgments of sovereign states outside Canada. Generally the international competence of foreign personal judgments is not recognized unless there was service of process within the foreign forum, ${ }^{45}$ and thus this premium on local service gives Quebec plaintiffs a reason to prefer service in the forum which does not now exist in the United States.

The charter filing requirements of American statutes are crude disclosure devices originally intended to protect local residents from a claim of ultra vires, a defense now largely eliminated in the United States. Quebec residents are not likely to face serious claims of ultra vires by Ontario's letters patent corporations, though the defense may still be open to corporations created by registration of memoranda of association. ${ }^{46}$ In Bonanza Creek Gold Mining Co. v. The King ${ }^{d 7}$.Viscount Haldane held that letters patent corporations are in nature the same as companies created by royal charter and "[i]n the case of a company created by charter the doctrine of ultra vires has no real application in the absence of statutory restriction added to what is written in the charter. Such a company has the capacity of a natural person to acquire powers and rights."

service out of the jurisdiction, which in certain cases is assimilated to service within. Although service out of the jurisdiction may be obtained in that province, it does not give jurisdiction to its courts. Article 94 [now Article 68] states directly the cases in which Quebec courts are competent ratione personae. J. Castel. Private INTERNATIONAL LAW 243 (1960) (footnotes omitted).

See generally W. JohnSON, Conflict of Laws 993-1044 (2d ed. 1962).

15The leading case is Forbes v. Simmons, 20 D.L.R. 100 (Alta. 1914). Recognition is also granted in a number of other situations which are listed at J. CASTEL, supra note 44, at 26164. See generally H. ReAd, Recognition AND ENFORCEMENT OF Foreign JUdGMENTS IN THE Common Law Units of the British Common wealth (1938).

"Canada's two methods of general incorporation are described in note 38 supra.

${ }^{17}[191611$ A.C. 566 (P.C.) (Can.).

is Id. at 583-84. But the matter is not entirely clear. Though the Bonanza Creek case "is generally interpreted as having held that an Ontario company was not restricted by the doctrine," the principle has been "put in confusion by the treat ment this subject has received 


\section{Corporation Officials}

The Companies Branch of the Department of Financial Institutions, Companies, and Cooperatives administers Quebec's foreign corporation law. During the year ending April 1, 1969, the Branch issued 69 licenses to extra-provincial corporations, most of which were from other provinces, ${ }^{19}$ and during the 10 -year period ending April 1, 1969, some 600 licenses were issued under the act.50 Fees for licenses are based on the amount of capital the corporation proposes to use in Quebec and are charged according to a tariff published by the Companies Branch. Most corporations pay the minimum fee of $\$ 100$ which is applicable where proposed local investment is $\$ 40,000$ or less. The Branch estimated the total amount of fees collected during the year ending April 1, 1969 was $\$ 10,000$ and that the total for the last 10 years was $\$ 100,000$.

The Director of the Branch said the foreign corporation law now serves two purposes in Quebec: the law facilitates the service of process on extra-provincial corporations and gives the Branch an opportunity to select out the powers of a corporation which it may not use in Quebec. As an example of the latter, the Director noted that a corporation cannot carry on the profession of engineering in Quebec, and therefore, its admission would be on the condition that it not use its professional powers in the province. The files of the Branch are open to the public and about 10 visitors a week request information which becomes available because of the extra-provincial corporation law.

The Companies Branch gives the Ontario exemption free rein. According to the current staff, the Quebec government, the Quebec Bar, and the public have accepted the practice without criticism.51

in Ontario jurisprudence since 1916." Legislative Assembly Select Committee on Company Law, Interim Report, 27th Leg., 5th Sess. 27 (Ont. 1967). The Select Committec was appointed during the last days of the 1965 session of the Assembly and instructed to review the province's corporation act and other related statutes. The Committee, with Allan $F$ Lawrence chairman, issued the interim report cited above and in 1969 continues its study with Gordon R. Carton chairman.

"The provincial statutes are applied to enterprises incorporated in other nations, a practice which is criticized at F. WEGENAST, supra note 14 , at 827 , but which raises questions beyond the scope of this article.

SoInterview with Roch Rioux, Director of the Companies Branch of the Quebec Department of Financial Institutions, Companies, and Cooperatives, and Paul A. Demers, Q.C.., Assistant Director of the Companies Branch, in Quebec, June 20, 1969.

${ }^{31}$ Interview with Martin-Claude LePage, Jacques Gingras, and Louise Lamarre, Legal 
The Branch Director thought there was no significant difference between the pattern of Quebec activity of Ontario corporations and the pattern of enterprises incorporated by other provinces. Because of the Bonanza Creek case, Ontario corporations can probably accept powers from Quebec not specifically granted in their charters though registered companies cannot, but this is a difference generally found between letters patent and registered companies. The Director knew of no reason to eliminate the exemption, and in a later interview said that he would personally be pleased if other provinces took advantage of the Quebec invitation because there is no reason to treat Manitoba, for example, differently than Ontario..$^{52}$

The report of the current staff was substantiated by the Branch's former Director, now Director of Legal Services for the Quebec Department of the Provincial Secretary ${ }_{,}^{53}$ who said that he had never received a complaint about the exemption during his fifteen years in the Branch. According to the former Director the arrangement was intended to facilitate trade between the two provinces and so he would not recommend that the exemption be changed. Although regarding questions about extension of the waiver as political in nature, he indicated his belief that Quebec would have nothing to lose. The former Director said that foreign corporation laws were originally revenue measures but that the fees are now insignificant.

\section{Tax Officials}

In the United States, proposals to simplify or eliminate state foreign corporation laws are often questioned on the ground that change would cripple state tax collection programs, and this concern is probably the major obstacle to reform. The Quebec Corporations Tax Act ${ }^{54}$ imposes taxes on paid-up capital, places of business, and net revenues. The Act requires that all three taxes be paid by "every incorporated company carrying on any undertaking, trade or business," 55 and the Act further defines these scope terms as

Advisers to the Companies Branch of the Quebec Department of Financial Institutions, Companies and Cooperatives, in Quebec, June 21, 1969.

${ }^{32}$ Interview with Roch Rioux, Director of the Companies Branch of the Quebec Department of Financial Institutions, Companies, and Cooperatives, in Quebec, July 3, 1969.

sI Interview with Louis de B. Gravel, Director of Legal Services of the Quebec Department of the Provincial Secretary, in Quebec, July 2, 1969.

"QUe. Rev. STAT, c. 67 (1964).

sId. $§ 3(1)$. 
meaning "exercising any of the corporate rights, powers or objects of a company or possessing any property in the Province or having therein a place of business." $" 56$ The application of the places of business tax is limited by further definition of places of business as either primarily offices or showrooms, ${ }^{57}$ and taxes on net income are limited by executive action which provides that corporations with "no establishment in Quebec" are exempted from net revenue taxes. ${ }^{58}$ Quebec also has a Retail Sales Tax Act ${ }^{59}$ which is imposed on the purchaser but which the seller must collect as agent for the province, the Act requiring corporations "whose establishment is outside the province" to make collections for Quebec in a number of broadly described situations. ${ }^{60}$ The Quebec corporation tax scheme is virtually a profile of state tax programs; the minor places of business tax and the reversal of the usual relative scope of the capital and income taxes are variations, but the collection problem is fundamentally the same in Quebec as in most states.

The Technical Director of the lncome Tax Division of the Quebec Department of Revenue said the Department has no peculiar problems with Ontario corporations. ${ }^{61}$ The Department now makes no significant use of information on file at the Companies Branch, though the Branch does notify the Revenue Department of requests to surrender charters, and occasionally officials of the Department read filed documents to see if corporations are in fact not organized for profit. Notices of admissions of corporations under the extraprovincial corporation law are published in the Quebec Gazette, the provincial register, but the Technical Director said that this is not a significant source of information for the Revenue Department. Furthermore, the Director pointed out that fifteen years of field

\footnotetext{
s/d. \& 2(9).

${ }^{57} / d$. $\S 3(\mathrm{t})(\mathrm{a})-(\mathrm{h})$.

so Order-In-Council No. 521, Regulations Under the Corporation Tax Act. \& 2(3). Feb. 28. 1961 (Que.).

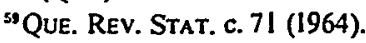

"1d. $\S \S 2(6),(12)$. The Act requires that all sellers register with the Department of Revenue before making sales of movable property in the Province. Section 27 of the Act provides that "[al person who has neither residence noy place of business in the Province cannot institute or continue any proceedings therein for the recovery of a debt arising from the sale or delivery of property to a person who resides or carries on business thercin, unless he holds a registration ccrtificate issued under this act," and thus brings into the sales tax law the forfeiture penalty so common in forcign corporation laws.

"Interview with Roland Brodeur, Technical Director of the Income Tax Division of the Quebec Department of Revenue, in Quebec, July 3, 1969.
} 
experience in Montreal and Quebec had convinced him that the Department's own investigation efforts are a more efficient and more reliable source of information than the general licensing requirements. The telephone book, he said, is the best directory of corporations doing business locally, and it is the primary starting point for the Department's tracing activities. The Department of Revenue would not oppose extension of the exemption to other provinces.

The best substantiation of the Director's report is the admission by a Department Tax Consultant that he did not know Ontario corporations were exempt from qualification requirements. ${ }^{62}$ The Consultant said he knows of no special collection problems concerning Ontario corporations and that he believes the exemption has no impact at all on the Revenue Department. He said that although one could deduce that the exemption makes it easier for Ontario corporations to avoid paying provincial taxes in Quebec, the actual effect of the waiver on collection activities is negligible.

\section{Attorneys}

Quebec corporation lawyers described the mutual exemption as a significant convenience. ${ }^{63}$ One member of the Quebec Bar said that it eliminates work which attorneys should not do simply because filling out forms is not the practice of law. He called compliance with foreign corporation laws a frustrating formality and recalled difficulties which he had encountered in getting charter copies satisfactorily certified for Newfoundland and Alberta. ${ }^{64}$ Another attorney thought the mutual waiver desirable because it is favorable to the development of trade and commerce, and was surprised that there are no similar exemptions in the United States..$^{65}$

\footnotetext{
"Interview with Jean Paul Drouin, Tax Consultant to the Quebec Department of Revenue, in Quebec, June 20, 1969.

-Interview with Philip F. Vineberg, Q.C., of the Quebec Bar, in Montreal, August 18, 1969; Interview with Alan Z. Golden of the Quebec Bar, in Montreal, July 24, 1969; Interview with Mitchell Klein of the Quebec Bar, in Montreal, July 24, 1969; Interview with Jean Marier of the Quebec Bar, in Quebec, July 3, 1969; Interview with Charles Stein, Q.C.. of the Quebec Bar, in Quebec, July 3, 1969. In 1963 Jean Marier, then a graduate student at the Harkard Law School, wrote that the Quebec-Ontario waiver "is important when we consider the trends towards free trade today and the removal of excessive burden of formalities which hampered economic growth." J. Marier, Foreign Corporation Doing Business in Quebec 9, Mar., 1963 (unpublished paper prepared for the International Tax Research Seminar at the Harvard Law School).

"Interview with Mitchell Klein of the Quebec Bar, in Montreal, July 24, 1969.

sInterview with Charles Stein, Q.C.. of the Quebec Bar, in Quebec. July 3, 1969.
} 
None of the attorneys interviewed reported knowledge of cases in which Quebec residents were injured by operation of the exemption. The local disclosure required by foreign corporation laws was considered to be of little value to practitioners because the information obtained is not as reliable as that on file in the provinces of incorporation, and, as a Montreal attorney observed, it is as easy to telephone Vancouver as Quebec, adding that one simply does not buy a British Columbia corporation on the basis of information filed at the Quebec Companies Branch.68

\section{THE ONTARIO EXPERIENCE}

Delivery of process to a corporation gives jurisdiction to an Ontario court and a court rule establishes a procedure for "service outside of Ontario by a writ of summons." ${ }^{\prime 67}$ However, the Ontario plaintiff, like his Quebec counterpart, ${ }^{68}$ gains some advantage by initiating a local suit against a corporation of another province by serving process in the forum. The Quebec premium for local service is established by Code of Civil Procedure Article 179 which controls, in part, the recognition of foreign judgments in the province and which provides that "[a]ny defense which might have been set up to the original action may be pleaded to an action brought upon a judgment rendered in any other province of Canada, provided that the defendant was not personally served with the action in such other province or did not appear in such action." ${ }^{9}$ Ultra vires defenses are probably not available to Quebec corporations acting in Ontario or elsewhere. Quebec incorporates by letters patent and, according to Bonanza Creek, the doctrine is not applicable in that case. ${ }^{70}$

\section{Corporation Offiçials}

The Companies Branch of the Ontario Department of Financial

\footnotetext{
${ }^{65}$ Interview with Alan Z. Golden of the Quebec Bar, in Montreal, July 24, 1969.

${ }^{67}$ ONT. SuP. CT. Civ. R. 25. The rule lists at least 15 circumstances in which service outside the province will be allowed. Rule 26 requires that application be made to the appropriate court before service under Rule 25 , and an application will not be granted if the plaintiff fails to show a prima facie cause of action or if Ontario is not a convenient forum. Practice AND Procedure iN Ontario 56a (1967). See J. Castel, supra note 44, at 237-38.

* See note 45 supra and accompanying text.

"Que. Code CIv. P. art. 179. The anomaly of this premium was pointed out by Professor Kurt Nadelmann: "In making personal service the criterion for inter-provincial recognition, Quebec has adopted the most un-civilian of all acceptable bases of jurisdiction." Nadelmann, Enforcenent of Foreign Judgments in Canada. 38 CAN. BAR Rev. 68, 83 (1960).

${ }^{70}$ See note 48 supra and accompanying text.
} 
and Commercial Affairs expects to grant 250 licenses under the Ontario foreign corporation law during the 1970 fiscal year, and the Branch estimated that about 2,000 corporations have been admitted under that part of the Corporations Act during the past 10 years.71 The minimum fee is $\$ 125$, and the amount increases according to the amount of capital which will be used in the province. The current annual revenue is expected to be $\$ 35,000$, and the total revenue for the past ten years was approximately $\$ 250,000$. A number of visitors come to the Companies Branch office in the Ontario Parliament Building each year, but the Branch did not know how many come for information filed because of the extra-provincial corporation law. The Director of the Companies Branch was frankly not certain what purposes the foreign corporation law now serves.

The exemption for Quebec enterprises is applied without limit, and neither the Director nor the Senior Legal Advisor knew of cases in which local residents had been injured by the waiver. However, one practice of the Branch in connection with the exemption has been criticized. The Senior Legal Advisor recalled that because there is no limitation on the entry of Quebec corporations, the Branch for many years refused to incorporate an Ontario enterprise with the same name as a Quebec corporation. Ontario residents complained that this unnecessarily limited names available for local use and the practice has now been modified to refuse a Quebec name only if the Quebee corporation is carrying on business in Ontario.

The Director noted no differences in the local activities of Quebec corporations and corporations from other provinces and said that he would not recommend elimination of the exemption, but rather in the spirit of making commerce between the provinces easier he would be pleased to see the exemption extended beyond its present limit.

\section{Tax Officials}

The Corporation Tax Act of Ontario ${ }^{72}$ imposes taxes on income and paid-up capital on "[e]very corporation that has a permanent establishment in Ontario," "73 and Ontario statutorily requires

\footnotetext{
"Interview with J.K. Young, Director of the Companies Branch of the Ontario Department of Financial and Commercial Affairs, and C.R.B. Salter, Senior Legal Officer of the Companies Branch, in Toronto, July 7, 1969.

${ }^{72}$ ONt. ReV. Stat. c. 73 (1960).

गId. $\S 3(1)$.
} 
collection of the retail sales tax by persons, including corporations, "who in the ordinary course of his business in Ontario, sells tangible personal property to a purchaser in Ontario." "The scope of the Ontario taxes is probably somewhat narrower than the Quebec tax. on capital or typical state income taxes, but the collection problem is substantially the same as in Quebec and most states.

The Chief of Administration of the Tax Branch and the Supervisor of the Tax Roll saw no peculiar problems with Quebec corporations. ${ }^{75}$ Until a few years ago there was virtually no exchange of information in Ontario between the Corporation Tax Branch of the Department of Revenue and the Companies Branch, but now a common computer is used and considerable data is automatically pooled. The Tax Branch, for example, receives a copy of information given the computer for each new admission under the foreign corporation law, and the computer furnishes yearly a list of corporations which made annual reports but did not file tax returns, but officials said that in terms of revenue production these two types of information are not significant. The Tax Branch estimated, in fact, that in nearly one-third of the cases information about corporations from other provinces acting in Ontario first comes to the Tax Branch and is then reported to the Companies Branch. No objection was indicated to extension of the exemption to businesses incorporated by provinces other than Quebec.

\section{Attorneys}

Ontario corporation lawyers regarded the mutual exemption as an advantage and reported no knowledge of cases where harm to local residents resulted because of the waiver. ${ }^{76}$ Most of the practitioners recognized some convenience in having information about corporations from other provinces on file in Toronto and specifically mentioned names and addresses of corporations, names and addresses of officers, directors, and agents, and, occasionally,

\footnotetext{
"An Act to impose a Tax on Retail Sales, 9 \& 10 Eliz. 2, c. 91, §§ 1(18), 6 (1961) (Ont.).

${ }^{73}$ Interview with F.G. Cholmondeley, Chief of Administration of the Corporation Tax Branch of the Ontario Department of Revenue, and K.S. Bone, Supervisor of the Tax Roll of the Corporation Tax Branch, in Toronto, July 8, 1969.

"Interview with R.C. Meech, Q.C., J.H. McC. McNair, S.B. Scott, and G.C. Stevens of the Ontario Bar, in Toronto, July 9, 1969; Interview with J.R. Finley of the Ontario Bar, in Toronto. July 8, 1969: Interview with Lorie Waisberg of the Ontario Bar, in Toronto, July 8. 1969 .
} 
incorporating documents. But nearly all said that such local information is useful only in a preliminary way, and is not absolutely necessary. One attorney explained his belief that when information is needed about, for example, a British Columbia corporation, the only reliable place to get that information is British Columbia. His usual practice is to employ a firm in the incorporating province to get the information, with an attendant request for an opinion letter stating that the material furnished is accurate. Occasionally, if time is of the essencc, information on file in Toronto might be very useful, but those occasions are rare, he said, and alone do not seem to justify a filing requirement. ${ }^{77}$ None of the attorneys would advise against extension of the present waiver.

The Ontario Legislative Assembly Select Committee on Company Law and its staff have collected an unusually valuable mass of information about corporate practice in the province. ${ }^{78}$ The best of a number of briefs given the Select Committee was submitted by the Commercial Law Subsection of the Ontario Branch of the Canadian Bar Association, and its general point of view of foreign corporations is consistent with that of the attorneys interviewed." The brief makes no criticism of the Quebec exemption and urges new efforts to simplify the admission of foreign corporations:

As corporation law becomes more complex, it is our belief that foreign corporations would rather do business within this province through a vehicle possessing powers and subject to limitations known to the corporation's own counsel or related to the jurisdiction where the head office of the corporation is located. We feel, therefore, that to encourage foreign corporations to come into Ontario efforts should be made to simplify and streamline the procedure for so doing and that in particular efforts should be made to arrive at uniformity of procedure among all the provinces of Canada."

\footnotetext{
, "Interview with R.C. Meech, Q.C., of the Ontario Bar, in Toronto, July 9, 1969.

"1"The Select Committee is described in note 48 supra. The Committee inserted advertisements in all Ontario daily newspapers and a number of periodicals advising the public of its existence and requesting oral or written briefs within the terms of reference of the Committce. In addition, letters inviting comment on the Province's laws were mailed to all corporations incorporated in Ontario or carrying on business in the province. LeGisLative assembly Select Committee on Company Law, Interim Report iii, 27th Leg., 5th Sess. (Ont. 1967). Copies of the written briefs and letters submitted to the Select Committee are in the Ontario Legislative Library.

7The Commercial Law Subsection of the Ontario Branch of the Canadian Bar Association, Brief submitted to the Legislative Assembly Select Committee on Company Law (unpublished document in the Ontario Legislative Library).

Id. at 47.
} 
No letter or brief submitted to the Committee criticizes the mutual exemption, and the Select Committee's Research Director knew of no proposal to eliminate the arrangement. ${ }^{81}$

\section{Three Alternatives}

In this period of corporation law revision in the United States, legislative committee members and their staffs must often ask what changes, if any, shall we propose for foreign corporations? Thus far the answers are disappointing because there has been no successful attempt to bring qualification statutes up to date. There are several reasons for this failure, including the fact that no analysis of the origin and current role of state laws controlling the admission of enterprises incor porated by other states has been available ${ }^{82}$ and that no record of substantial change exists as a source for proposals and a support for reform.

The experienee of Quebec and Ontario suggests three alternatives for draftsmen and furnishes information on the feasibility of each. The first, of course, is to leave matters substantially the way they are today in most states, and the application of the Quebec and Ontario laws to the group of non-exempt corporations demonstrates that this is manageable.

A second alternative is the elimination of traditional foreign corporation laws and the substitution of statutes requiring only annual reports. The reports might, for example, include statements of names, addresses of principal offices, jurisdictions of incorporation, and addresses of officers and directors. Fees of $\$ 10$ to $\$ 20$ could be charged to cover costs and produce a small amount of revenue, and fines could be provided in cases of failure to file. The

\footnotetext{
${ }^{81}$ Interview with Saul Schwartz, Research Director of the Ontario Legislative Assembly Select Committee on Company Law, in Toronto, July 9, 1969. The topic of foreign corporations was not covered in the Select Committee's Interim Report and consideration of that topic and others continues. A memorandum prepared for the committee notes but does not comment on the Quebec exemption. F. Nugan, Memorandum to the Select Committee on Company Law, Topic Number 48, Foreign Corporations 3 (unpublished document in the Ontario Legislative Library). The restrictive proposals of the memorandum seem to conflict with the recommendations of the bar group, but the memorandum is by its own terms only tentative: "[T]he submissions to follow are made out of a desire to suggest practical improvements, in the present law, but with a realization that they constitute opinions and suggestions only. So little thinking and writing on foreign corporation problems has been done in Canada to date that one is inclined to qualify even the least of submissions." $I d$. at 7.

${ }^{82}$ Hopefully this deficiency is now remedied by Walker, supra note 29 , and Walker, supra note 32 .
} 
Quebec-Ontario experience shows that such a change is possible because this alternative is fundamentally the scheme which each province has applied to corporations from the other for nearly forty years. The major conditions which adoption of the second alternative would eliminate from typical state codes are those relating to service of process and charter copies. The experience of the two provinces shows that in a legal setting similar to that of most states these elements can be dropped without harm to local residents or significant tax evasion, and with the gain of considerable convenience. The only concern consistently expressed in interviews was that general free entry might result in name conflicts. But two solutions to this problem are apparent, and either could operate as a part of the second alternative: the first is to recognize that the judge-made law of most states gives considerable protection to first in time users of corporation names, and this remedy may be sufficient. ${ }^{83}$ The second solution to the name problem is to require the registration of all corporate names used locally on a first in time, first in right basis as a part of now fairly common business names registration plans. ${ }^{84}$ The second solution is especially attractive because it would prevent most name conflicts before they occur and probably avoid some litigation.

Finally, a third alternative suggested by the joint experience is the elimination of qualification without the substitution of annual reports, leaving tax returns as the primary government contact of most corporations from other states. As a part of this alternative revenue departments could be required to furnish to the public on request certain information such as the names of corporations, jurisdictions of incorporation, office addresses, and names and addresses of officers and directors. Any name problems could be

vSee American Clay Mfg. Co. v. American Clay Mfg. Co., 198 Pa. 189, 47 A. 936 (1901) and the cases collected at Annot., 66 A.L.R. 948, 952-53 (1930). On reflection several of those expressing concern said similar Canadian remedies were probably enough protection.

${ }^{81} \mathrm{~A}$ detailed proposal for a central registry for corporate and business names with a requirement that similar names not be registered is made at Legislative AsSEmbly Select Commitree on Company Law, INterim Report 22-23, 27th Leg., 5th Sess. (Ont. 1967). The proposal is based on The Business Names Registration Act, 14 Eliz. 2, c. 8 (1965) (Man.) and the Registration of Business Names Act, 6 \& 7 Geo. 5, c. 58 (1916). The major present purpose of the Ontario proposal and the Manitoba and British Acts is to require registration of persons and corporations doing business under names other than their own, but only the addition of a requirement that true names be registered would be necessary to enlarge these statutes to meet the need discussed in the text. 
resolved by either of the solutions suggested above. The mutual exemption experience assures only that the second alternative is possible, but Quebec and Ontario public officials and attorneys predicted that annual report requirements could also be eliminated without harm. The Director of the Ontario Companies Branch doubted the present value of annual returns received from corporations chartered by other provinces, ${ }^{85}$ and, of the three alternatives described here, preferred the third, provided the possible problem of name conflicts could be solved. The Director of the Quebec Companies Branch thought the third alternative practical although he said that those interested in maintaining the private nature of tax returns might cripple any proposal to give selected information to the public. ${ }^{88}$ Ontario tax officials believed the third alternative would not create tax collection problems and said the change could be adopted in their province. ${ }^{87}$ The Tax Roll Supervisor, a computer expert in the modern Ontario Tax Branch, added that a computer with a random selection capability could make information from corporation tax returns almost instantly available to the public. ${ }^{88}$ The Technical Director of the Quebec Income Tax Division said that adoption of the third alternative would not dry up significant sources of information for the Revenue Department. ${ }^{89}$ The use of computers by the Quebec government is more limited than in Ontario, and public access to portions of tax returns would probably require a revision of corporation return forms so that one page of information could be either copied or separated from the rest of the return. ${ }^{90}$

\footnotetext{
${ }^{25}$ Interview with J.K. Young, Director of the Companies Branch of the Ontario Department of Financial and Commercial Affairs, and C.R.B. Salter, Senior Legal Officer of the Companies Branch, in Toronto, July 7, 1969.

sInterview with Roch Rioux, Director of the Companies Branch of the Quebec Department of Financial Institutions, Companies, and Cooperatives, in Quebec, July 3, 1969.

${ }^{8}$ Interview with F.G. Cholmondeley, Chief of Administration of the Corporation Tax Branch of the Ontario Department of Revenue, and K.S. Bone, Supervisor of the Tax Roll of the Corporations Tax Branch, in Toronto, July 8, 1969.

${ }^{83}$ The Ontario Tax Branch at the time of the interview did not have such a capability, but officials said there is a major need for the necessary equipment and hope that it can soon be purchased.

8'Interview with Roland Brodeur, Technical Director of the Income Tax Division of the Quebec Department of Revenue, in Quebec, July 3, 1969.

${ }^{90}$ There are plans in Quebec for development of a central business data system to collect from government sources information about all business enterprises in the province. Intcrview with Pierre Blouin, Bureau of Statistics of the Quebec Department of Industry and Commerce,
} 
Attorneys in both provinces generally agreed that elimination of multiple returns would be a major convenience, ${ }^{91}$ with one calling the prospect a delight.92 The third alternative also received considerable support from the brief of the Ontario Branch of the Canadian Bar Association which suggested that annual reports by foreign corporations be related to tax returns:

It is suggested that the time for filing be related to the corporation's fiscal year and the filing of the return be attached to the filing of financial returns to the taxation authorities in the various provinces which levy corporate income tax. The subcommittee feels that corporations would attach more importance to the filing of an annual return if it were to be filed at the same time as the tax returns. ${ }^{\text {3 }}$

\section{CONCLUSION}

The fundamental truth which should guide state corporation law draftsmen as they choose betwcen these three alternatives is that the self-interest of states is most often served by encouraging corporations from other states to carry on local business. The primary basis for this principle is the theory of international trade which demonstrates that after trade occurs all participants have a larger volume of all goods from the employment of a given amount of resources than would be the case in economic isolation. The production of goods is a social cost, and so an increase in the volume of goods produced by the same effort is a net social gain.94 Consequently, draftsmen who seek to change corporation statutes to increase social welfare should make choices which tend to encourage rather than discourage commerce among the states.

in Quebec, July 4, 1969. Such a computer center would be an ideal place to file a single annual return. Appropriate portions of the return could be printed out to other government departments, and non-confidential information could be made available to the public.

"Interview with Philip F. Vineberg, Q.C.. of the Quebec Bar, in Montreal, August 18, 1969; Interview with Alan Z. Golden of the Quebec Bar, in Montreal, July 24, 1969; Interview with Mitchell Klein of the Quebec Bar, in Montreal, July 24, 1969; Interview with R.C. Meech, Q.C., J.H. McC. McNair, S.B. Scott, and G.C. Stevens of the Ontario Bar, in Toronto, July 9. 1969; Interview with J.R. Finley of the Ontario Bar, in Toronto, July 8, 1969; Interview with Lorie Waisberg of the Ontario Bar, in Toronto, July 8, 1969; Interview with Jean Marier of the Quebec Bar, in Quebec, July 3, 1969; Interview with Charles Stein, Q.C., of the Quebec Bar, in Quebec, July 3, 1969.

"Interview with J.R. Finley of the Ontario Bar, in Toronto, July 8, 1969.

"The Commercial Law Subsection of the Ontario Branch of the Canadian Bar Association, Brief submitted to the Legislative Assembly Select Committee on Company Law 47-48 (unpublished document in the Ontario Legislative Library).

"These economic principles are briefly described and useful sources are cited in Walker, supra note 29, at 753-55. 
The principle is particularly applicable to the regulation of the commercial entities of other federal partners. The states of the United States and the provinces of Canada have acknowledged by their acts of union and confederation the economic benefits of membership in vast common markets, and their successful experiences should be reason enough to encourage choices at every step which are frankly intended to stimulate commerce across intranational boundaries. This policy is not altruistic, but urges draftsmen concerned with corporations from other states to make all choices with regard to the best interests of their constituents.

There may be particular types of enterprises or particular problems common to several types which require special state concern. In these cases lack of local controls may increase costs to local residents so that the net effect is a decrease in trade, making increased local control fully consistent with the economic basis of the principle. But solutions to such specific problems should not be applied to all corporations from other states because the result, as to most, is the addition of a meaningless and costly formality.

According to the standard of encouraging trade, the first of the three alternatives suggested by the experience of Quebec and Ontario is undesirable. Foreign corporation laws have become complicated schemes which make the movement of corporate enterprises among the states needlessly difficult. The original reason for qualification is lost, the conceptual foundation of the statutes is largely discredited, major new purposes have not developed, and in a number of aspects the laws themselves have caused trouble and promise more. The second alternative would be a significant improvement over present conditions. Requirements only of brief annual statements would provide disclosure at least arguably necessary to reach significant information about out-of-state corporations while substantially reducing the present burden of compliance. The third alternative seems the most desirable. The elimination of foreign corporation laws, leaving tax returns the primary government contact of most corporations from other states, would end unnecessary regulation, focus effort at the point of current major state interest, and, most importantly, encourage trade.

The obviously legitimate need to recommend legislation capable of being enacted may dictate in particular cases that some variation 
of the "middle-of-the-road" second alternative be proposed; or that either the second or the third alternative be proposed to operate on a reciprocal basis with other states willing to adopt similar reforms. Such changes would represent noteworthy progress toward the goal of encouraging commerce among states in a nation of limited resources and ever increasing social responsibilities. 
